\title{
Forestry policy in the United Kingdom
}

\author{
Further commentaries
}

Opposite viewpoints on the great British forest policy debate were presented in the February and June 1973 issues of the Chronicle by Harry Smith and Jack Thirgood. They were, in a way, a reflection of the differences of opinion within the United Kingdom over the Forestry Poicy statement, which was circulated as a consultative document in June 1972 by the Ministers responsible for forestry in England, Scotland and Wales. This document was accompanied by a cost/benefit analysis undertaken by a team led by economists from the Treasury.

Interested bodies were invited to submit their views on these two documents - and did so in considerable numbers! As Professor Thirgood pointed out, the general tenor of the comments was critical, especially of certain aspects of the methodology and findings of the cost/benefit study. Having digested these comments over a 15-month period, the Government announced its preliminary conclusions on the general lines of future policy for forestry to the House of Commons on 24 October 1973.

Here, JACK THIRGOOD and T. J. PECK present their views on the outcome of the deliberations.
Extracts from the announcement made in the House of Commons of last October are given below.

\begin{abstract}
Within our limited land surface and the increasing pressures upon it, the Government are concerned that forestry should form part of a really effective pattern of rural land use, in which it is harmonised to the best possible advantage with agriculture and the environment. Accordingly the Forestry Commission, in administering grant aid to private forestry, will consult with the Agricultural Departments and local planning authorities on land use and amenity aspects of woodland owners' proposals. The Commission's regional Advisory Committees will be reconstituted to include representatives of agricultural and local planning and amenity interests as well as members representing the forestry industry and will have the function of advising both on broad area strategy and on individual cases of doubt arising in the administration of grants. There will thus be much improved arrangements for ensuring proper weight is given to amenity considerations. Additionally my Rt. Hon. Friends and I have asked the Chairman of the Forestry Commission specially to ensure that, in carrying out the Commission's own operations as well as in the exercise of their functions as Forestry Authority, every possible opportunity is taken to encourage and secure effective integration between agriculture and forestry.

Such is the importance which the Government and all those with whom they have consulted attach to land being properly used, and thus being well managed over the long term, that we propose to introduce a new Dedication Scheme more directly linked with these objectives. This single Scheme will succeed the previous Dedication, Approved Woodlands, and Small Woods Planting Grant Schemes, and its terms will differ from those for woodlands that are already dedicated. Thus in future a Dedication covenant will normally terminate when approved felling takes place, but with the provision for rededication. Owners entering the Scheme will receive an outright acreage payment as and when approved planting or re-planting takes place, in return for accepting a continuing obligation to manage the woodland concerned in accordance with plans of operations designed to secure sound forestry practice, effective integration with agriculture and environmental safeguards, together with such opportunities for recreation as may be appropriate.

"My Rt. Hon. Friends and I hope that the remaining consultations will be concluded before the end of the year and further details, including rates of grant, will then be announced. In the meantime, the Forestry Commission will model its own planting and management policies upon the principles I have described; will give still further emphasis to providing recreational facilities: and will develop a planting and re-planting programme, on the lines and at the level set out in the Consultative Document, and with special regard paid to the contribution which the Commission's operations can make towards stemming depopulation in rural areas".
\end{abstract}

\section{T. J. Peck's view}

The consultations referred to by the Minister have not yet, apparently, resulted in every detail being finalised. Agreement has, however, been reached on certain aspects of the new Dedication Scheme. Reports indicate that the initial rate of grant will be set at $£ 45$ per hectare (roughly $\$ 43$ / acre, converting at $\$ 2.35$ to the pound and 2.47 acres to the hectare) for softwood plantations and $£ 125$ per hectare ( $\$ 119 /$ acre) for plantations where there will be a "predominantly hardwood appearance for the greater part of the life of the woodland". Discussions have continued on how to define "predominantly hardwood appearance" in practice and on the minimum area which will qualify for grants. (Canadians may be puzzled by the strong preference for hardwoods for amenity reasons expressed by some people in Britain and the antipathy to the planting of softwoods. The latter is partly a reaction to past planting "abuses" -

\section{Jack Thirgood's view}

While consultations will continue on more detailed aspects, the statement has been greeted by the national Forestry Societies as a reversal of the policies advocated in the 1972 Consultative Document, that together with the associated cost-benefit study caused the initial furor.

The Announcement, which is published in the January, 1974 issue of Scottish Forestry, has to a great extent removed the uncertainty regarding the development of the state and private forestry estate and the fears that, as the editor of Scottish Forestry remarked, its development might grind to a halt. In the case of state forestry, the implication that an alternative means of ameliorating unemployment might militate against forestry expansion has been modified and the Forestry Commission have been enjoined to model their own planting and management policies upon the principles described in the Announcement, to pay special regard "to the con- 
Peck (cont.)

aesthetically speaking - with exotic species, including some from western North America, such as Sitka spruce and Douglas fir!)

The initiative for the forest policy review came from the Conservative Government of $\mathrm{Mr}$ Heath, which narrowly lost the General Election of 28 February 1974 . The return of a minority Labour Government under Mr Wilson could conceivably throw a spanner in the works so far as the up-dating of forest policy is concerned. The political tightrope that Labour will have to walk until a new election will likely prevent, however, the introduction of more radical proposals for improving social equity. Nevertheless, it is possible that the new Government may take the opportunity, while forest policy is still in the melting pot, to keep the debate alive on the extent to which it remains in the national interest to "subsidize" private landowners and other investors in forestry, notably those in a position to benefit from the generous concessions contained in the present tax laws.

The change of Government has not been the only event to overtake the policy review. Since work on it began in 1971, the Conservative Government successfully negotiated the United Kingdom's entry into the European Community, which became effective on 1 January 1973. The new Government, in accordance with its election promise, is seeking to renegotiate the terms of entry. Assuming that the UK will remain a member - many in the country would not be unhappy to see it withdraw from the Community altogether - the latter's agricultural policy could have important effects on rural land use patterns in the United Kingdom. It might, for instance, become much more attractive to raise sheep there. Other developments have been the major upheavals in international commodity markets, including those for forest products, with price increases probably without precedent in Europe, parity changes and, more recently, the "energy crisis". Each in its way has implications for investment in forestry in the UK, but it may take some time before it becomes clear what the implications are precisely.

\section{The cost/benefit study}

Let's take a look in some detail at one of the main bones of contention in the UK forestry debate: whether or not the cost/benefit study was a useful exercise. Professor Smith, in his article, contended that the study brought "clear, competent thinking $\ldots$ to bear upon the problems of forestry...", and that the study "illuminates the issues and documents desirable new directions...". Professor Thirgood acknowledged that "economic analysis is an important tool in policy determination", but countered this by saying that "we should never delude ourselves into thinking that it is the major or even most important consideration in deciding a national course of action." When the statement of 24 October 1973 is compared with the original policy statement of June 1972, the impression is gained that the UK Government did not
Thirgood (cont.)

tribution their operations can make towards stemming depopulation in rural areas" and to "give still further emphasis to providing recreational facilities".

A mechanism for formal regional consultation with agricultural, local planning and environmental interests is to be set up in place of the presently existing informal arrangements. Such an interdisciplinary approach has been consistently advocated by the national societies. Financial support for private forestry will continue at much the same level as in the past though with certain differences in detail. Essentially, presently existing agreements will remain in force but new entrants will enter a new single streamlined Dedication Scheme that will replace the present Dedicated, Approved and Small Woodland Planting Grant Scheme. Dedication will continue to require that work be done under an approved plan of operations. On felling, the agreement will terminate and the owner will then be free to re-dedicate his land to forestry. This will allow the owner to change the land use if he wishes, a flexibility that was lacking in the previous arrangements. Details of the new grants scheme have not yet been published but the Joint Announcement states that "the total of continuing payments ... should be broadly the same as would have been obtained it fhe old Schemes had remained open to new entrants" and that "an appreciably higher planting where a significant proportion of hardrate of grant will be available for planting or rewoods is involved".

The Forestry Committee of Great Britain, representing the private sector and members of the Timber Growers' Organisation and the Scottish Woodland Owners' Association, have responded with a statement which included the following:

The ministerial statement represents a significant change in Government thinking since the consultative document of June 1972 - a reversal caused, amongst other factors, by the world timber crisis with its drastic repercussions on house building, the supply of newsprint and the balance of payments ... the Government have now recognised British timber production in itself as the basis for grant support.

Indicative of the changed attitude are the remarks made by the Chairman of the Forestry Commission, Lord Taylor of Gryfe, at a ceremony in September, 1973 to celebrate the planting of the millionth acre by the Forestry Commission in Scotland. Lord Taylor said:

Provided proper attention is given to maintaining natural beauty, forests managed primarily for timber production can contribute as much to amenity and the landscape as any other feature. It is the Commissioners' belief that when foresters integrate their silviculture and forest management with due consideration for landscaping, wildlife conservation and recreation, the forest reaches its full potential.

These accomplishments surely entitle us to claim that the valuable newly created national resource of our forests represents a great national asset. In this regard the Commissioners acknowledge the part played by private woodland owners and the forest industry.

As I suggested last year might well be the case, "objective analytic" methods and "the establishment of success in financial terms" have not pre- 
allow itself to be heavily influenced by the findings of the study. Nor for that matter is there any indication that it took much notice of the considerable weight of comment which the study elicited.

Does this mean, then, that the whole exercise of involving the public was just a political whitewash? Personally, I do not think so. Whatever the original motives behind it, the cost/benefit study served a useful purpose in bringing into the open a number of issues, such as the wasted effort of trying to establish plantations on sub-marginal forestry land, the ambiguous economics of using forestry to stem rural depopulation and the declining importance, under present-day conditions, of maintaining a strategic timber reserve, to mention only three. Such issues had been insufficiently thought through and may now be discussed in a more rational and less emotional way than before, at least partly because of the analysis of them in the cost/benefit study.

Some contend that the application of the tools of economics, such as cost/benefit analysis, is inappropriate to a 'natural' resource such as forestry. Others feel that it is worse than a waste of time to measure the immeasurable, such as the intangible benefits of the forest. Maybe so, but if these critics really wish to see the forest managed to the best benefit of society, they must surely accept that there is a need to find some kind of a mechanism by which to evaluate objectively what society wants and how this matches up to what the forest can provide. Subjective value judgements are unlikely to be good enough on their own, and any objective method of assessment of demand and supply is likely to be better than none, provided it is used judiciously and its limitations are clearly recognised. However well or badly the UK cost/ benefit study measures up to the latter qualifications, I feel that it should still be recognised as a rather remarkable trail-blazing effort. For quite understandable reasons, most of the work in this field up to now has been long on theory and short on practical application. The UK study, however, went as far as estimating, and submitting the estimates to critical public scrutiny, such intangibles as future recreational demand, effect of plantations on water supply and the social cost of creating jobs in forestry.

Critics will say that a good policy maker will reach the right decision, using experience and intuition, without the aid of such gimmicks as cost/ benefit analysis. I would challenge that on two grounds. Firstly, the very act of putting a figure on something makes people stop and think about it a little more - especially if they disagree with it! It is surely far more helpful to a discussion to start with some estimates of values, however rough, than merely to observe, say, that the recreational value of the forest will increase faster than that of the wood produced, ergo take this into account in future planning. The onus is on the critics of the value estimates to come up with something better. The UK study, after explaining carefully how
Thirgood (cont.)

vailed in this further evolution of British forest policy. Rather, it seems that Dawkins' Phase 3 has been ushered in and the reign of Maximum Social Benefit confirmed. Indeed Crawford (Scot. Forest. 28:7-13), concerned for future wood supplies in a situation of world scarcity, has complained at the lack of reference in the government policy statement to the forest as timber, and believes that environment, amenity, recreation and agricultural aspects are clearly the main objective of the British Forest of the future. While this is an overstatement, nevertheless the general orientation is clear. But in any case the rapid changes of the last year in the circumstances in which British forestry is conducted, detailed by the National Forestry Committee, have clearly indicated the meaninglessness, in an era of rapid social and economic change, of excessive dependence on attempted long term economic analysis using present techniques and N.D.R. in policy determination.

As Dr Smith suggested initially, there are indeed lessons to be learnt from this British exercise.

the figures were obtained, gives the following estimates ( $f / a c r e)$ of timber revenues and recreational gross benefits (note the distinction between revenues and benefits here), discounted at $10 \%$ to prevent values:

\begin{tabular}{lllll} 
& N. Wales & S. Scotland & \multicolumn{2}{c}{ N. Scotland } \\
Timber revenues & $7(16.45)^{*}$ & $3.5(8.23)$ & $1.5(3.53)$ \\
Recreation values & $8(18.80)$ & $3.5(8.23)$ & $5 \quad(11.75)$
\end{tabular}

*Figures in brackets are approximate dollar equivalents.

It is immediately apparent from the above that, even allowing for large errors in estimation, the importance of recreation values in the future cannot be overlooked. Bear in mind, also, that the recreational values per acre shown above are low compared with those for forests nearer to the main centres of population.

Secondly, such things as tradition, emotion, vested interests, administrative convenience and idealism, although worthy enough in themselves in the right context, are notoriously unreliable as aids in decision-making, mainly because they contain subjective biases and value judgements.

Lest this commentary on cost/benefit analysis, as exemplified by the UK study, begins to appear too uncritical, I should mention some of the study's short-comings. These are not so much the methodologies or assumptions employed, although one can quibble at such things as the inflexibility of using only one test discount rate $(10 \%)$, the failure to follow through the implications of an expanded forestry program for domestic wood-processing industries and trade, or the failure to place the study 
within the context of the forestry situation at the international level, given the UK's heavy reliance upon overseas supplies. My disappointment is, rather, that not enough care seemed to be taken, either while the study was in preparation or in the report on it, to explain clearly to the public at large and the interested parties its purpose and objective, its precise role in relation to the forestry policy review, and the limitations put on its findings by the quality and quantity of many of the input data. In particular, for many foresters and laymen alike, confusion and doubt arises as to the role of economics in dealing with problems of a non-economic nature, as in a cost/benefit study.

The terms of reference of the study did, admittedly, state that the object was "to provide information on the costs and benefits involved in the Forestry Commission's future planting programme, and possibly in the development of policy in relation to their existing plantations..." and "... to clarify what the nation gets in return for accepting ... low rates of return". Unfortunately, however, the impression might be given by the way the study is constructed that the objective was firstly, to prove that the wood-producing role of forestry was uneconomic in the UK, and from there to search around for other possible reasons, such as recreation, rural employment and import substitution, which might justify the continuation of a planting programme. This may have created the impression of a program in search of a policy. The incorporation of all possible costs and benefits, tangible and intangible, into the model at the beginning would have demonstrated that some of them were not being treated as after-thoughts, while the endresult of the study would have been the same. It would have thus avoided a good deal of the misunderstanding and scepticism that has surrounded the study since it was issued and has tended to cloud its many good features.

In brief, the study was an example of the problem, which seems to be all too frequent in the field of forestry these days, of a breakdown in communications - perhaps failure to establish proper communications would be more accurate - both within the sector itself and between the sector and "outsiders" with a direct interest in it.

\section{Conclusion}

Professor Thirgood feels that the lesson we can learn from the story of British forestry is the virtue of flexibility. To this we can all surely add a hearty
"Amen". We should, however, distinguish between the blown-by-the-wind flexibility exhibited by the Vicar of Bray and the flexibility which takes as a starting point objective assessments of the present and future interests of society that Professor Smith and all of us would like to see. No one would deny that these interests in the UK, as elsewhere, are moving strongly away from the concept of forestry as a purely commercial, wood-producing operation towards a more balanced use of the forest land. A too abrupt shift in policy, however, to meet this evolving pattern of demand, if taken without at least some objective assessment of its impact on the forestry sector in particular and society in general, is just as liable to result in errors as has sometimes happened in the past.

Another conclusion which could be drawn from the discussion above is that economists have not been successful in explaining to the public, including interested professionals from other disciplines, that economics is far more than commercial accounting of costs and revenues. It is deeply concerned, and increasingly so, with finding ways to express in comprehensible and comparable terms all the factors, tangible and intangible, which affect human welfare.

Finally, more understanding of their respective problems and capabilities on the part of the various disciplines that have inputs into forestry would make a major contribution towards more effective policy formulation and implementation. Winston Churchill once said something to the effect that the Americans and the British were two peoples with a common destiny, only separated by. language. Even among foresters, different specialization groups sometimes suffer from the same communications problem. The first step for each group or discipline should be to take just a little extra trouble to make sure that it is being correctly understood and interpreted by the others. They might all be pleasantly surprised to find how much in common were their viewpoints and their destinies.

The same applies to foresters separated by the Atlantic. Despite the marked differences in styles and scales, there is much in Canadian forestry that the British, or should I say European, foresters can learn from Canada. Similarly, European forestry has much to offer Canadians. The UK cost/benefit study, the debate which it has generated and developments which can be expected to result from them should be worth following by foresters in Canada. 